Dicle Tıp Dergisi / Dicle Med J (2019) 46 (4) : 871-875

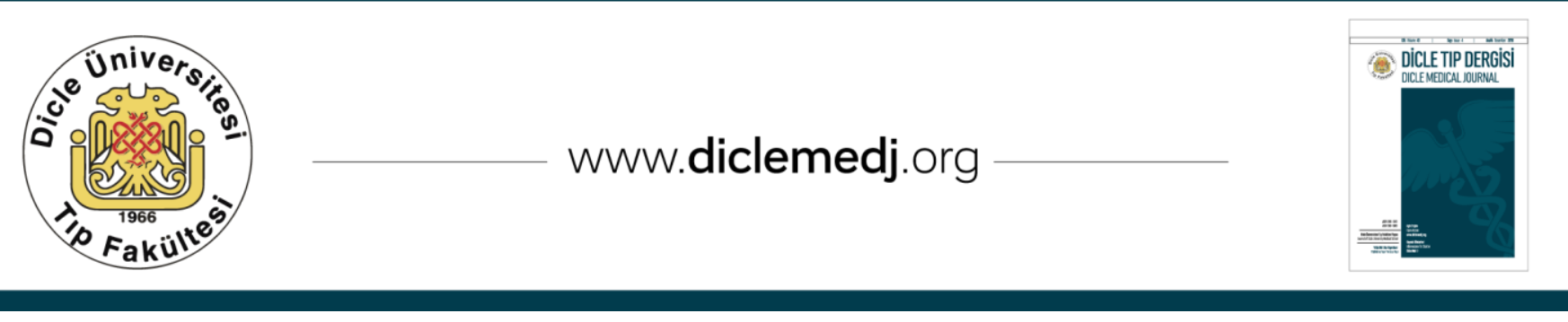

Olgu Sunumu / Case Report

\title{
Kolon adenokarsinomu ve yaygın diffüz büyük B hücreli lenfomaya sekonder prostat tutulumu: Nadir bir olgu
}

\author{
Muhammed Cihan Temel ${ }^{1}$, Serkan Akan², Caner Ediz ${ }^{3}$, Neslihan Kaya Terzi ${ }^{4}$, Ömer Yılmaz \\ 1 Sağllk Bilimleri Üniversitesi Sultan Abdülhamid Han Eğitim ve Araştırma Hastanesi, Üroloji Servisi, İstanbul, Türkiye 0RCID: 0000-0002-8677-8504 \\ 2 Sağllk Bilimleri Üniversitesi Sultan Abdülhamid Han Eğitim ve Araştırma Hastanesi, Üroloji Servisi, İstanbul, Türkiye 0RCID: 0000-0002-6066-0401 \\ 3 Sağllk Bilimleri Üniversitesi Sultan Abdülhamid Han Eğitim ve Araştırma Hastanesi, Üroloji Servisi, İstanbul, Türkiye 0RCID: 0000-0001-9717-1209 \\ 4 Sağllk Bil. Üniversitesi Sultan Abdülhamid Han Eğitim ve Araştırma Hastanesi, Patoloji Anabilim Dall, İstanbul, Türkiye 0RCID: 0000-0001-8184-4691 \\ 5 Sağllk Bilimleri Üniversitesi Sultan Abdülhamid Han Eğitim ve Araştırma Hastanesi, Üroloji Servisi, İstanbul, Türkiye ORCID: 0000-0002-4433-9431
}

Geliş: 29.01.2019; Revizyon: 31.07.2019; Kabul Tarihi: 19.09.2019

Öz

Primer veya sekonder lenfoma prostatta görülen en nadir malignitelerdir. 64 yaşındaki erkek hasta halsizlik, bulantı ve kilo kaybı şikâyetleri ile kliniğimize başvurdu. Gastrointestinal sistem değerlendirmesi sonucunda kolonoskopide çekum / çıkan kolon seviyesinde görülen ülserovejetatif kitleden biyopsi alındı ve sonuç adenokarsinom olarak raporlandı. Evreleme amaçlı yapılan F-18 Fluorodeoksiglikoz Pozitron Emisyon Tomografi görüntülemede; Yumuşak dokuda ve çıkan kolonda diffüz, boyun-mediasten-akciğer-kas grupları içerisinde ve batında lokalize olmak üzere çok sayıda hipermetabolik kitle ve sol femurda litik özellikli lezyon görüldü.

Prostat bezi sol üst lateralde yerleşimli yoğun hipermetabolik odak (SUVmax: 18.4) izlendi. Ürolojik değerlendirmede digital rektal muayene ve prostat spesifik antijen normaldi. 12 kor prostat iğne biyopsisi yapılan hastada bir korda CD 20 ve BCL 2 pozitifliği, CD 3 negatifliği görüldü. Diğer doku biyopsileri ile uyumlu olarak prostatın sekonder diffüz büyük B- hücreli lenfoması olarak raporlandı. Eş zamanlı kolon adenokarsinomu, yaygın metastatik diffüz büyük B hücreli lenfoma ve buna sekonder prostat lenfoması görülen bu olguya benzer vaka sayısı literatüre bakıldığında oldukça nadir olup; Dijital rektal muayenesi normal olan ve prostat spesifik antijen düzeyi normal saptanan hastalarda metastaz olabilme ihtimalinin dışlanamayacağını akılda tutmak gerekir.

Anahtar kelimeler: Prostat, diffüz büyük b hücreli lenfoma, kolon adenokarsinomu 


\title{
Colonic adenocarcinoma and prostate involvement secondary to diffuse large B-cell lymphoma: a rare case
}

\begin{abstract}
Primary or secondary lymphoma is the most rare malignancy seen in the prostate. A 64 year old male patient was admitted to our clinic with complaints of fatigue, nausea and weight loss. As a result of the gastrointestinal system evaluation, biopsy was taken from ulcerovegetative mass at the level of cecum / ascendant colon by colonoscopy and the pathology result was reported as adenocarcinoma. F-18 Fluorodeoxyglucose Positron Emission Tomography was performed for staging; Multiple hypermetabolic masses were found in the neck, mediastinum, lung, various muscle groups and abdomen. Diffuse hypermetabolic areas were observed in the soft tissue and the ascendant colon. Lytic lesions were detected in the left femur. Intense hypermetabolic focus located on the left upper lateral of the prostate were seen (SUVmax: 18.4).

Digital rectal examination and prostate-specific antigen were normal in urological evaluation. Prostate biopsy was performed. In a core of prostate biopsy; CD 20 and BCL 2 positivity, CD 3 negativity was found and it was reported as secondary diffuse large B-cell lymphoma of the prostate consistent with other tissue biopsies. The number of cases similar to this case with simultaneous colon adenocarcinoma, metastatic diffuse large B cell lymphoma and secondary prostate lymphoma is rare in the literature. The possibility of lymphoma metastasis to prostatic tissue should not be ignored in patients with normal digital rectal examination and prostate-specific antigen levels
\end{abstract}

Keywords: Prostate, diffuse large b cell lymphoma, colon adenocarcinoma.

\section{GíRiş}

Adenokarsinom prostatta en sik görülen primer malignitedir ${ }^{1}$. Primer veya sekonder lenfoma ise prostatta görülen en nadir malignitelerdir ${ }^{2}$. Non-Hodgkin lenfomada prostat tutulumu yaklaşık \%0,2 - 0.8 oranındadır ve tüm prostat neoplazmlarının \%0,1' ini oluşturur ${ }^{3,4}$. Bu olguda kolon adenokarsinomu tanısı ile eş zamanlı saptanan prostatta gelişen diffüz büyük B-hücreli lenfoma metastazını sunmayı amaçladık. Bu vakayı sunmamızdaki amaç çok nadir görülen; Prostata metastaz yapmış Diffüz Büyük B hücreli lenfomanın eş zamanlı olarak kolon adenokarsinomu ile birlikte görülebildiğini ve PSA yüksekliği olmadan da metastatik prostat lenfomasının görülebileceğini bilim dünyasıyla paylaşmaktır. $\mathrm{Bu}$ ve benzer şekilde senkron görülen kanser triadları tanımlandıkça belki de gelecekte bunlara yönelik moleküler ve genetik çalışmalar patolojik alt yapılarını açlklayabilecektir.

\section{OLGU}

64 yaşındaki erkek hasta halsizlik, bulantı ve 2 ay içerisinde $13 \mathrm{~kg}$ kilo kaybı olması şikâyetleri ile başvurdu. Öyküsünde ek hastalık saptanmadı. Klinik değerlendirme sonucu planlanan kolonoskopide çekum / çıkan kolon seviyesinde görülen ülserovejetatif kitleden biyopsi alındı ve adenokarsinom olarak raporlandı. Evreleme amaçlı gerçekleştirilen F18 Fluorodeoksiglikoz Pozitron Emisyon Tomografi (FDG PET) görüntülemede; yumuşak dokuda ve çlkan kolonda diffüz, boyunmediasten-akciğer-kas grupları içerisinde ve batında lokalize olmak üzere çok sayıda hipermetabolik kitle, sol böbrek toplayıcı sisteminde grade 2 dilatasyon ve sol femurda litik özellikli lezyon görüldü. Prostat bezi sol üst lateralde yerleşimli yoğun hipermetabolik odak (SUVmax: 18.4) izlendi (Şekil 1). Kolon adenoca tanılı bu hastada tarif edilen görüntü "öncelikle kolon ve prostat maligniteleri akla gelmekle birlikte yüksek grade lenfoproliferatif hastalıklar da düşünülmelidir" şeklinde raporlandl. 


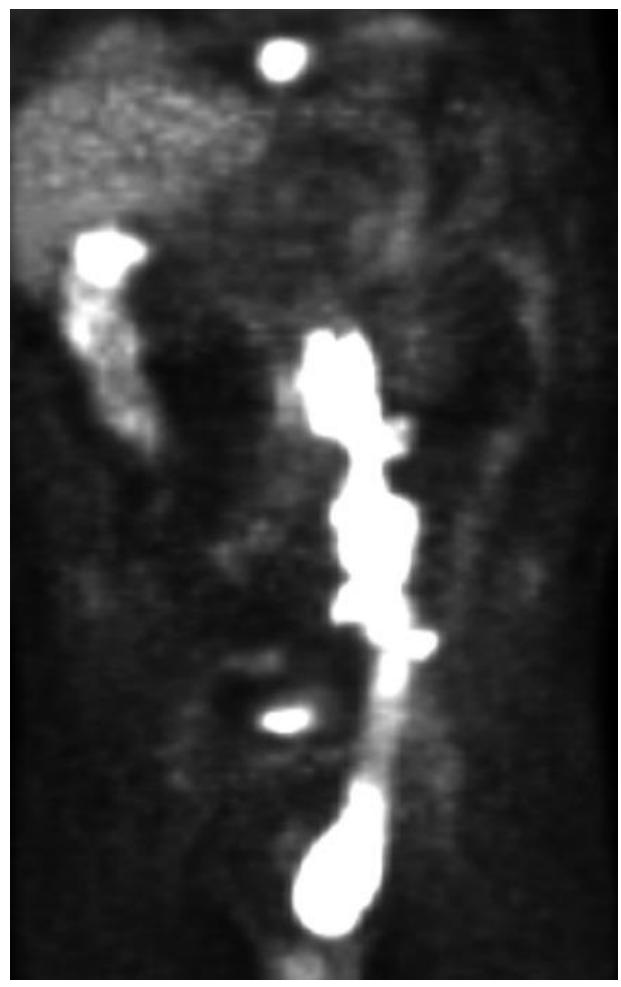

Şekil 1: F-18 Fluorodeoksiglikoz Pozitron Emisyon Tomografi (FDG PET): Yumuşak dokuda ve çıkan kolonda diffüz, boyunmediasten-akciğer-kas grupları içerisinde ve batında lokalize olmak üzere çok sayıda hipermetabolik kitle ve sol femurda litik özellikli lezyon. Prostat bezi sol üst lateralde yerleşimli yoğun hipermetabolik odak (SUVmax: 18.4) izlendi.

Prostat lezyonuna yönelik yapılan sorgulamada üriner sisteme ait spesifik bir şikayet saptanmadı. Dijital rektal muyanede, prostat dokusu normal boyutta ve kıvamı elastik olarak değerlendirildi. Laboratuvar incelemesinde böbrek ve karaciğer disfonksiyonu düşündürecek bulgular; Kreatinin, aspartat aminotransferaz, alanin aminotransferaz, gama glutamil transferaz ve laktat dehidrojenaz yüksekliği görüldü (Kreatinin: $1.59 \mathrm{mg} / \mathrm{dL}$, AST: $62 \mathrm{U} / \mathrm{L}, \mathrm{ALT}: 38 \mathrm{U} / \mathrm{L}, \mathrm{GGT}: 70 \mathrm{U} / \mathrm{L}, \mathrm{LDH}$ $780 \mathrm{U} / \mathrm{L}$ ). Prostat spesifik antijen normaldi $(0.86 \mathrm{ng} / \mathrm{mL})$. Batın içerisi ve prostat dokusundaki lezyonlara yönelik yapılan değerlendirme sonucunda, kemik iliği, inguinal lenf nodu ve prostat biyopsisi yapılması planlandı. Transrektal ultrason eşliğinde, önce FDG PET'de tarif edilen lezyona yönelik ve sonrasinda da standart prostat biyopsisi uygulandl. Toplamda $12(2+10)$ kor prostat dokusu biyopsi örneği alındı. İmmünohistokimyasal incelemede $1 / 12$ adet örnekte CD 20 ve BCL 2 pozitifliği, CD 3 negatifliği görüldü. 11 adet doku örneğinde ise tümör saptanmadı ve benign prostat dokusu olarak yorumlandı. Patoloji sonucu; Prostat biyopsisi haricindeki yapılan doku biyopsileri ile uyumlu olarak prostatın sekonder difüz büyük B- hücreli lenfoması olarak raporlandı. Kolon mukozasından alınan biyopsi materyali tekrar incelendiğinde adenokarsinom tanısı değişmedi (CDX2 ve CK20 pozitif) (Şekil 2).

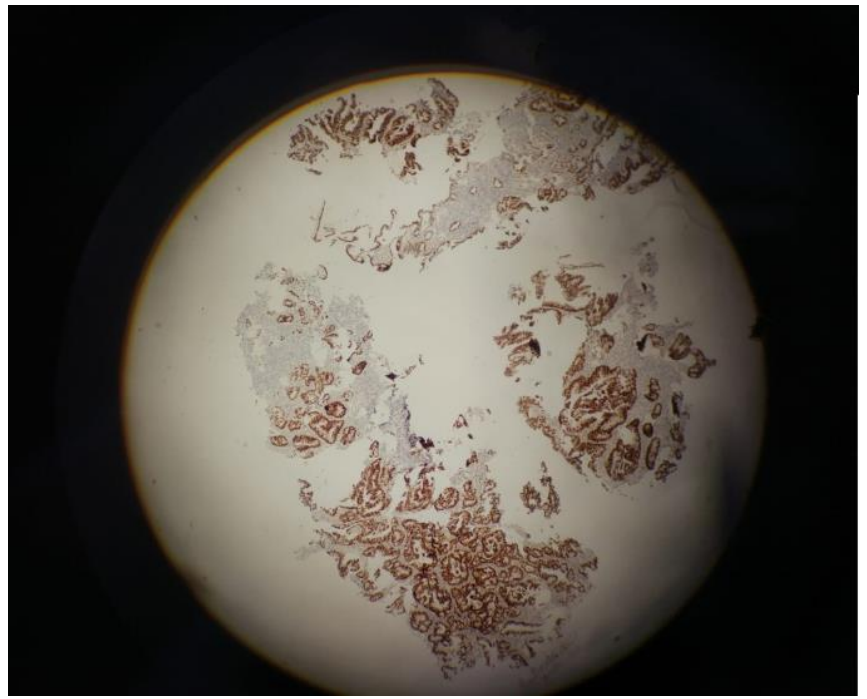

Şekil 2: Kolon mukozasından alınan CDX2 ve CK20 pozitif biyopsi materyali (Hematoksilen\&Eosin boyası X 200).

Hastaya hematoloji tarafından 3 kür etoposide, prednison, vinkristin, siklofosfamid, doksorubisin ve rituksimab (EPOCH-R) tedavisi verildi. Bu tedaviden fayda gören hastanın daha sonra Siklofosfamid, doksorubisin, vinkristin ve prednizon (CHOP) tedavisine de duyarlı olduğu belirlenerek 3 kür CHOP tedavisi verildi. Hasta bu tedavilerle remisyona girdi, sol hidronefroz düzeldi ve takibe alındı. Takip protokolüne alınan olgudan "Bilgilendirilmiş gönüllü olur" belgesi alınarak tanı ve tedavi prosedürlerinin bilimsel amaçlı olarak kullanılacağı bilgisi verildi. 


\section{TARTIŞMA}

Prostat kanserlerinin adenokarsinom haricindeki diğer histolojik alt tipleri sadece \%5-10 civarındadır. Büyük ardışık serilere bakıldığında Chu ve ark tarafından yapılan bir çalışmada; Prostatektomi, transüretral rezeksiyon ve iğne biyopsi örneklerinden oluşan 4831 spesimenin \%0,3'ünde (15 olgu) lenfoproliferatif hastalıklar olduğunu belirtmiştir ${ }^{2}$. Prostatik lenfoma olgularının $\% 65$ 'i sekonder tutulumdur 5 . Genellikle benign prostat hiperplazisi ve prostat adenokarsinomasına benzer şekilde 60 yaş civarında görülmektedir.

Lenfomalarin prostat tutulumu siklikla alt üriner sistem semptomları ve/veya akut üriner retansiyon şeklinde klinik vermektedir. $\mathrm{Bu}$ bulgulara ek olarak parmakla rektal muayenede prostat büyümüş ve yumuşak kıvamda saptanabilir ${ }^{6}$. Prostat lenfomasında serum PSA düzeyinin yüksekliği tipik bir özellik değildir ${ }^{7}$. Olgumuzun yapılan ürolojik değerlendirmesinde asemptomatik olması, dijital rektal muayenenin normal olarak değerlendirilmesi ve PSA değerinin artış saptanmaması tanıdaki zorluğu ortaya koymaktadır.

Çelik H. ve arkadaşları, iki kez akut üriner retansiyona girmiş ve prostat spesifik antijen düzeyi normal olan 63 yaşındaki bir erkek hastayı sunmuşlardır ${ }^{8}$. Transüretral rezeksiyon (TUR) uygulanan bu hastanın TUR materyalinin mikroskopik incelemesinde, difüz lenfositik infiltrasyonun olduğu ve güçlü CD20 ve CD5 pozitif ve CD3 negatif boyandığı görülmüştür. Bizim vakamızda metastatik prostat lenfoması görülmesine rağmen herhangi bir şiddetli alt üriner sistem semptomu görülmemiştir.

Siklofosfamid, doksorubisin, vinkristin ve prednizon (R-CHOP) ile kombine rituksimab tedavisi, ileri evre Diffüz Büyük Hücreli Lenfoma hastaları için standart tedavi protokolü olarak kabul edilmektedir ${ }^{9}$. Bizim olgumuz da bu tedaviden fayda görmüștür.
Hastada eş zamanlı kolon adenokarsinomu, yaygın metastatik diffüz büyük $B$ hücreli lenfoma ve buna sekonder prostat lenfoması görülmüștür. Literatür araştırıldığında diffüz büyük B hücreli lenfomaya eşlik eden sekonder prostat lenfoması ve ek olarak kolon adenokarsinomunun görüldüğü olgu sayısı yok denecek kadar azdır. Moleküler ve genetik araştırmaların gelecekte bu alt yapıyı açıklayacağını düşünmekteyiz.

\section{SONUÇ}

Prostat dokusunun lenfoma metastazları tanısı son derece güç bir hasta grubudur. Primer tanısı genellikle insidental (Diğer nedenlerle yapılan tetkikler sonucu rastlantısal) olarak saptanmaktadır. Özellikle ileri yaş hastalarda gastrointestinal maligniteyi düşündüren yakınmaların yanısıra ürolojik yakınmalar birliktelik gösterirse, tüm ürolojik değerlendirmeler normal olsa dahi metastaz değerlendirmesi açısından dikkatli olunmalıdır.

Çıkar Çatışması Beyanı: Yazarlar çıkar çatışması olmadığını bildirmişlerdir.

Finansal Destek: Bu çalışma her hangi bir fon tarafından desteklenmemiştir.

Declaration of Conflicting Interests: The authors declare that they have no conflict of interest.

Financial Disclosure: No financial support was received.

\section{KAYNAKLAR}

1. Grignon DJ. Unusual subtypes of prostate cancer. Mod Pathol. 2004 Mar; 17: 316-27.

2. Chu PG, Huang Q, Weiss LM. Incidental and concurrent malignant lymphomas discovered at the time of prostatectomy and prostate biopsy: a study of 29 cases. Am J. Surg Pathol. 2005; 29: 693-9.

3. Wazait HD, Al-Buheissi SZ, Dudderidge T, et al. Rare case of primary lymphoma of the prostate: Giving the patient the benefit of the doubt. Urol. Int. 2003; 71: 338-40. 
4. Petrakis G, Koletsa T, Karavasilis V, et al. Primary prostatic lymphoma with components of both diffuse large B-cell lymphoma (DLBCL) and MALT lymphoma. Hippokratia. 2012; 16: 86-9.

5. Bostwick DG, Iczkowski KA, Amin MB, et al. Malignant lymphoma involving the prostate. Cancer 1998; 83: 732-8.

6. Antunes AA, Dall'Oglio M, Srougi M. Primary lymphoma of the prostate: a rare cause of urinary obstruction. Int. Braz. J. Urol. 2004; 30: 410-2.
7. Bostwick DG, Iczkowski KA, Amin MB, et al. Malignant lymphoma involving the prostate: Report of 62 cases. Cancer 1998; 83: 732-8.

8. Celik H, Cimen S, Akpolat N. Prostatın Nadir Görülen Bir Neoplazisi: Küçük Lenfositik Lenfoma. Bulletin of Urooncology. 2014; 13: 182-3.

9. Essadi I, Ismaili N, Tazi E, et al. Primary lymphoma of the head and neck: Two case reports and review of the literature. Cases J 2008; 1: 426. 